\title{
Big Data and Changes in Audit Technology: Contemplating a Research Agenda
}

\author{
Salijeni, George* \\ Samsonova-Taddei, Anna** \\ Turley, Stuart**
}

\begin{abstract}
This study explores the most recent episode in the evolution of audit technology, namely the incorporation of Big Data and Data Analytics (BDA) into audit firm approaches. Drawing on twenty-two interviews with individuals with significant experience in developing, implementing or assessing the impact of BDA in auditing, together with publicly available documents on BDA published within the audit field, the paper provides a holistic overview of BDA-related changes in audit practice. In particular, the paper focuses on three key aspects, namely: the impact of BDA on the nature of the relationship between auditors and their clients; the consequences of the technology for the conduct of audit engagements; and the common challenges associated with embedding BDA in the audit context. The study's empirical findings are then used to establish an agenda of areas suitable for further research on the topic. The study is one of the first empirical accounts providing a perspective on the rise of BDA in auditing.
\end{abstract}

* University of Manchester and University of South Wales

** University of Manchester

Keywords: auditing; methodology; data analytics; Big Data 


\section{INTRODUCTION}

The extant auditing literature contains considerable evidence of how audit firms have responded to public questioning of the quality of audit work and the social relevance of the audit function with methodological developments designed to restore confidence in the effectiveness of the audit process (Power, 2003; Robson et al., 2007; Curtis \& Turley, 2007; Carpenter \& Dirsmith, 1993). It has been argued, for example, that the introduction of statistical sampling, the audit risk model and business risk auditing sought to represent auditing as a scientific process to promote a picture of the seemingly objective, almost 'factual' nature of evidence gathering. The use of confidence levels and the determination of materiality underpinning statistical sampling and the audit risk model provided the metrics through which professional judgements were easily converted into 'facts' (see Carpenter \& Dirsmith, 1993 for statistical sampling; Maclullich, 2003 for Audit Risk Model). This paper focuses on the most recent episode in the evolution of audit technology, namely the incorporation of Big Data ${ }^{1}$ and Data Analytics (BDA) into audit firm approaches. Whilst the rise of BDA is clearly not the only example of methodological experimentations in auditing over the years, it is a particularly intriguing case as it brings out concerns as to whether Big Data-driven audit environments placing significant technical demands on auditing and increasing its remoteness may, in fact, be contributing to marginalization of the audit function itself (Alles, 2015). One possibility, therefore, is that BDA may eventually be seen as a disruptive audit innovation. This study provides the first empirical account of the developments, methodological challenges, and possible consequences of the adoption of BDA in audit methodologies with an ultimate aim to generate a meaningful agenda for further research on the topic.

Big Data relates to the nature of data (Arnaboldi et al., 2017; Gatner, 2012) whereas Data Analytics refers to the collection of tools developed to make sense of Big Data. We refer to 'BDA' to capture the relationship between the two terms as well as suggesting that the audit technologies being investigated in this study relate to those interrogating Big Data. The

\footnotetext{
${ }^{1}$ Gartner (2012) defines Big Data as "high-volume, high-velocity and high variety information assets that demand cost effective, innovative forms of information processing for enhanced insight and decision making". Most scholarly, technical and professional publications embrace these three key elements of volume, variety and velocity (e.g. Chen et al, 2012; Accountancy Futures Academy, 2013). Volume recognizes the magnitude of data, variety refers to how datasets may contain both structured and unstructured data, and velocity reflects how data capture and processing technologies are increasing the speed of analysis. Some have sought to extend the definition to include other attributes such as variability (in the pattern of data capture), veracity (indicating the risks associated with some forms of data) and the value of information (see discussion in Gandomi and Haider, 2015).
} 
potential impact of BDA as a major development in the delivery of audits has been recognized in the professional auditing community internationally (IAASB, 2016). The predominant view of the significance of Big Data for auditing is reflected in the following comment from one professional body:

The quantity of data produced by and available to companies, the replacement of paper trails with IT records, cloud storage, integrated reporting and growing stakeholder expectations for immediate information - any one of these alone would affect the auditing process, but Big Data is bringing them all, and more, at the same time.(ACCA, 2015)

As a consequence, large international audit firms, particularly the Big Four, have all made statements about the development of BDA tools to navigate and make sense of the vast data stores now available within and outside client organizations (Accountancy Futures Academy, 2013; IAASB, 2014; EY, 2014; KPMG, 2014) and invested significant amounts in projects designed to advance the technology (Brown-Liburd et al., 2015; Cao et al., 2015). William (2013, p. 556) argued, in this regard, that a technology such as BDA could "come to play a greater role in the regulation of [auditors] themselves, imposing a greater visibility and transparency on their activities". Such statements by auditors and audit commentators point to the developments around BDA in auditing as a major area of innovation in auditing worthy of investigation and provide a context for this paper. To date, audit scholars have devoted most attention to contemplating the potential impact of Big Data Analytics (BDA) on auditing conceptually (Brown-Liburd et al., 2015; Cao et al., 2015), with little being known about how developments affect the actual practice of auditing in the setting of an audit firm.

In contrast to much of the initial literature on this subject, which offers mainly normative accounts of the nascent developments in BDA and auditing, and lack empirically drawn insights, this exploratory study makes a contribution to the debate by providing empirical insights into such developments from the perspective of the auditors themselves. In particular, drawing on twenty-two interviews with individuals who both are highly experienced in auditing and have had significant roles in developing, implementing or assessing the impact of BDA in auditing, together with publicly available documents on BDA published within the audit field, the paper provides a holistic overview of BDA-related changes in audit practice, focusing in particular on three key aspects. First, we look for evidence of the extent to which the development and use of Big Data is re-configuring the relationship between auditors and their clients, leading to changed approaches to the storage, analysis and utilization of financial and other information. Second, we investigate how investment in BDA within audit firms is 
changing audit methodology, that is, the manner in which auditors are conducting various steps of the audit process, from planning to evidence collection, analysis and reporting. Third, we provide an overview of the common practical challenges of embedding BDA in audit work. We then draw on the study's findings to establish an agenda of areas suitable for further research concerning the actual impact of data analytics on daily audit practice from technical, economic and professional perspectives. In this regard, this study can be distinguished from prior accounts acknowledging the need for more research into the influence of BDA on audit practice (see, for example, Appelbaum et al., 2017) as we draw on the findings from fieldwork to offer an empirically grounded discussion of issues that warrant further scholarly investigation.

The paper is structured as follows. The next section sets out the background context and existing literature on BDA, in general and in relation to auditing, and places BDA in the context of broader developments in audit methodology over time. This is followed by a section describing the approach employed to collect evidence on this emerging topic before the main analysis section presents an evaluation of the status of BDA developments relative to auditing. The final discussion and conclusions section summarizes findings and contemplates an agenda for future research on the evolving field of financial statement auditing and BDA.

\section{DEVELOPMENTS IN AUDIT TECHNOLOGY AND BDA}

Historically, developments in audit technology have been promoted by auditors as technical improvements to the standard of audit work (Power, 2003). As a result of such developments, the process of conducting an audit has been subject to continuous objectification, formalization and streamlining (Newton \& Ashton, 1989; Fisher, 1996). A significant feature of the literature on developments in audit practice has been the apparent tension between 'structure' and 'judgement' (Cushing \& Loebbecke, 1986, Turley \& Cooper, 1991), where the risks and economics of the firm create an imperative for more structure and more programmed methodologies to promote efficiency and cost saving (Newton and Ashton, 1989) which can appear to conflict with the desire to represent auditing as an activity involving a high degree of individual, professional and expert judgement.

Prior studies have argued that the introduction in audit methodology of developments such as statistical sampling, the Audit Risk Model and Business Risk Auditing followed a 
pattern of representing auditing as the collection of objective, almost 'factual' evidence. Matthews (2006) demonstrates, for instance, how the introduction of statistical sampling in the early 1960s was portrayed as addressing the claimed deficiency of conventional methods of evidence gathering at the time to meet the conditions of a changing business environment characterized by significant growth in the volume of transactions. Increasing complexity and volume of available audit evidence motivated auditors to seek more cost-effective approaches to audit planning, while at the same time managing clients' expectations and demands as to the standard of audit work. The rise of statistical sampling provided an opportunity for auditors to legitimize the reduction in the volume of audit evidence by using mathematical techniques that invoked trust in the sampling process. In particular, the use of confidence levels in the application of statistical sampling provided the metrics through which auditors' professional judgements were easily converted into conclusions that they could justify more easily to their clients (Carpenter \& Dirsmith, 1993; Elliot \& Jacobson, 1987; Mathews, 2006). Therefore, the use of statistics in the audit evidence collection and evaluation process was aimed at increasing confidence in choices regarding sample sizes (Higson, 2003) as well as shielding auditors from potential challenges to their judgements (Sully, 1974). Similarly, further technological developments in audit leading to the rise of the Audit Risk Model and, later, Business Risk Auditing have also been interpreted in terms of reinforcing the legitimacy of the audit process (Hansen \& Messier Jnr, 1986; Power, 1997; Robson et al., 2007; Curtis \& Turley, 2007). Curtis and Turley (2007), for example, argue that, in the late 1990s, the world's largest audit firms made significant efforts to influence public perceptions of the Business Risk Audit model as a major innovation in audit methodology with "a potential to enhance audit effectiveness ....[and] the best way in which an auditor will be able to recognize management fraud and business failure risks" while, at the same time, dismissing concerns that the technology could be used to "redefine auditing as consulting and to facilitate identification of opportunities for providing value added services to clients, with the intention of improving the status and profitability of the auditor" (pp. 439-440). The rise of BDA in auditing should therefore be understood in the longer term historical context of the above developments in audit technology and auditors' attempts to promote technological solutions for the problem of maintaining (or restoring) the legitimacy of the audit function.

In the audit context, BDA has been commonly defined as "the science and art of discovering and analyzing patterns, identifying anomalies, and extracting other useful information in data underlying or related to the subject matter of an audit through analysis, 
modeling, and visualization for the purpose of planning or performing the audit" (AICPA, 2014, p.5). Comprehensive discussions focused around BDA and auditing first started in North America, with audit commentators and regulators making statements to acknowledge that the audit environment is becoming a Big Data environment. For instance, the American Chartered Institute of Public Accountants (AICPA) in 2012, while not specifically mentioning BD, launched a number of initiatives designed to highlight the importance of data in the provision of audit and assurance services, including the establishment of the Assurance Service Executive Committee Technologies Task Force to develop guidance and foster conceptual debate on the role of BD in audits (Zhang et al, 2012).

Whist it is often acknowledged that the rise of BDA in auditing is still in its early stages, the use of analytics in the audit process is not necessarily a recent phenomenon. Audit firms have been using computer based analytical tools since as early as the 1960s when the firms first developed Computer Assisted Audit Techniques (CAATs) to interrogate data in ways that could assist procedures such as audit sampling (Cushing \& Leobbecke, 1986). Some years later, in the early 1980s, computed vendors started to offer off-the-shelf analytical tools such as Audit Command Language (ACL) and Interactive Data Extraction and Analysis (IDEA) that later became used by the majority of audit firms as part of their analytical suites. The two latter technologies may be seen as the prototypes of what is now regarded as BDA in terms of their ability to tackle large datasets. What also paved the way to the current BDA architecture were changes in the manner in which audit clients manage information through technology. Some prominent examples include the platforms collectively classified as Enterprise Resource Planning (ERP) which enable companies to store and process information flows between different business units in an organization (O'Leary \& Markus, 2006). It is the proliferation of technological processes and mechanisms, including those mentioned above, aimed at capturing and processing vast amounts of information, that has given rise to the acknowledgement within accountancy firms that contemporary business environments are increasingly characterized by the digital phenomenon called Big Data, and that this has relevance for the audit, too.

All the major Big Four audit firms have invested significant amounts of money in recent years to either acquire or develop BDA tools. For example, KPMG's 2014 Transparency Report stated that the firm, in collaboration with technological companies (such as the McLaren Technology Group, better known for Formula One racing), had established a \$100 million (£74.8million) investment fund aimed at developing data analytical capabilities that could significantly transform audits and create value for clients. Similarly, EY has committed 
US\$400 million to develop audit innovation, including new audit support tools such as BDA (Ernst and Young Transparency Report, 2014). Also, PwC announced they have developed Halo, i.e. an in-house analytical tool to replace ACL and IDEA and to become "a next generation software application that analyses and assures data using a suite of algorithms" (PwC, 2014). Other, particular smaller audit firms often make use of off-the-shelf analytics software such as Spotlight, Lavastorm and Alteryx (ICAEW, 2016) to leverage their BDA capabilities.

Responding to the above developments in audit practice and methodology, recent audit literature has offered some initial assessment of the potential relevance of BDA to auditing, particularly in areas of risk assessment and performance of substantive and analytical procedures (Alles, 2015; Cao et al, 2015; Yoon et al, 2015; Krahel \& Titera, 2015; Wang and Cuthbertson, 2015; Alles \& Gray, 2016; Appelbaum et al., 2017). Cao et al. (2015), for example, suggest that BDA provides opportunities for auditors to navigate messy data at a faster rate and to create patterns and trends which can provide a more microscopic visualization of risks associated with the audited entity, assisting in determining the level of materiality. Yoon et al (2015) evaluate Big Data as a compliment for more traditional audit evidence, judged against conventional criteria of sufficiency, reliability, relevance and cost benefit. Further, these papers also note that a significant aspect of BDA in auditing is the challenge that large amounts of information can create for the auditor's professional judgement. BrownLiburd et al. (2015), for instance, argue that, while BDA offer auditors a plethora of ways of analyzing data, issues such as the ambiguity of information, information overload, and inability to navigate data to identify relevant information could undermine the benefits of utilizing BDA. Krahel and Titera (2015) suggest that such shortcomings could be addressed through the incorporation of BDA in formal auditing standards, to eliminate uncertainties in some areas of judgement. In this regard, auditing regulators at national and international level have also acknowledged the potential effects of Big Data on auditing (Fisher, 2015). Appelbaum and colleagues (2017), identify areas of auditing most affected by the rise of BDA and provide an overview of the content of relevant audit regulations and research to formulate a range of topics that require attention from the audit firms, standard setters, and academics. Whilst highlighting the pressing need for more empirical work into the developments with BDA and auditing, the paper does not explore such developments through a form of empirical engagement directly with audit firms themselves but draws its conclusions from an assessment of publicly available information. In 2013, IAASB established a taskforce to investigate the effects of BDA on 
auditing, but, to date, no action has been taken to signal the need to revise the auditing standards beyond the publication of discussion papers seeking the views of relevant stakeholders (IAASB, 2014, 2016).

The existing audit literature, therefore, provides predominantly technique-oriented, normative accounts of auditors' engagement with BDA, making inferences as to the possible as opposed to the actual impact of such developments on contemporary audit practice. In contrast, this paper offers instead an empirically informed analysis of the developments with regards to the growing utilization of BDA in audit work drawn from the personal reflections of auditors themselves and other documentary evidence on the relevant topics. The resulting empirical findings are then used as a basis for contemplating a stimulating agenda for future research into the rise of BDA in auditing.

\section{RESEARCH METHODOLOGY}

In this study, we have adopted a qualitative approach to explore the issues pertaining to the rise of BDA in auditing and the effects of those on the practice of auditing. The paper relies on evidence collected through semi-structured interviews as well as a wide range of documentary sources.

Potential interviewees for the study were first approached during the Accountancy Europe (formerly known as Fédération des Experts Comptables Européens (FEE)) audit conference in June 2015 in Brussels themed "Long Term Vision and Short Term Challenges", where two leading ERPs developers (Oracle and SAP) and two of the Big Four audit firms (KPMG and PwC) made presentations on Big Data implications on financial reporting and relevance of BDA for audits of financial statements, respectively. Attendance at this event provided an opportunity to discuss informally with auditors and stakeholders issues relating to BDA. Some of the discussions resulted in formal interviews to further explore the issues addressed in the informal meeting. A 'snowballing' approach was followed whereby, drawing on these initial interviews, we developed a network of contacts of individuals with knowledge of and experience in BDA tools in the context of an audit. As a result, between July 2015 and January 2017, we conducted twenty-two semi-structured interviews with twenty individuals (see Table 1), including auditors from the Big Four and mid-tier audit firms mainly in the UK but also in EU countries such as Belgium and Italy as well as members of the audit regulatory bodies in the UK and Belgium. All interviewees have had a particular active involvement with 
BDA in the audit field, and together they represent three types of interaction with BDA: (i) responsibilities with respect to the development of BDA methods within audit firms, (ii) implementation of BDA on audit engagements, and (iii) evaluation of the impact of BDA for standard setting and other regulatory perspectives. Many have spent lengthy careers as practicing auditors and hold senior positions within their firms' hierarchies. Furthermore, several interviewees from the Big Four and mid-tier audit firms also hold positions as members of the IAASB Data Analytics Working Group (DAWG), which indicates their high-level role with regards to issues around audit methodology and BDA in their respective firms. Four participants from the audit firms were interviewed twice, and three representatives of audit regulators were interviewed as a group.

Interviews ranged in length between 30 minutes and two hours, and were tape-recorded. During the interviews, participants were asked questions following an agenda designed to cover a range of topics (for an overview, see Appendix), including: their role and how it is related to $\mathrm{BDA}$; the key developments with regards to BDA within their respective organization and in the audit field in general; what aspects of BDA they consider most useful/relevant to them personally, their organizations, and their clients; the current state of development with regards to BDA and any related challenges; and the impact of BDA on various aspects of the audit process and its organization. Participants were encouraged to discuss points beyond the structure of the interview questions but which could be considered as relevant to BDA in the audit of financial statements.

\section{INSERT TABLE 1 ABOUT HERE}

In addition, one of the authors attended five one-to-one practical sessions where the use of BDA tools was demonstrated in a practical setting, with a possibility for follow-up questions and discussion. One session was conducted on the premises of a mid-tier audit firm, and the remaining sessions were in the offices of the Big Four firms. The sessions were between 20 and 45 minutes long and focused on the practical application of BDA tools in areas such as assessment of internal controls, analysis of journal entries, risk assessment, compliance with particular auditing standards (e.g. ISA 240), and visualization, among others. Due to concerns over competition, the author was only allowed to voice record the sessions. However, notes were taken and also sketches were drawn of the tools whenever possible during and immediately after the sessions. 
We also supplemented the evidence from interviews with analysis of a wide range of documentary sources, including materials from websites of audit firms, audit regulatory agencies, and professional accountancy bodies; and the audit firms' transparency reports and presentations relating to the topic of BDA in auditing (see Table 2):

\section{INSERT TABLE 2 ABOUT HERE}

We adopted an interpretive approach to analyzing the empirical evidence collected. Considering our primary objective is to provide a holistic view of the rise of BDA in auditing that could enable a meaningful research agenda, we sought to capture in our analysis the complexity of the rise of BDA not only as an instance of technological change in the delivery of an audit but also a social phenomenon that has potential consequences for the relevance of auditing as a professional practice. In particular, with regards to the analysis of the interviews with audit practitioners, we sought to understand how they are relating to BDA technology and the manner in which their engagement with these tools has an impact on their approaches to audit work and their understanding of their role as an auditor. In addition, interviews with members of the regulatory community provided further context on the way in which BDA developments in auditing are being considered for their potential impact on issues such as the notion of audit quality, audit professionalism, and auditor ethics; but regulatory matters are not the focus of this paper explicitly. We utilized Nvivo, a qualitative data analysis tool, to identify recurring 'expressions' and 'narratives' (Humphrey et al., 2017; O'Dwyer et al., 2011) that were representative of the most commonly expressed views as to the implications of BDA for auditing. While analysing the interviews, however, we were aware of the potentially problematic nature of the audit environment, especially at a time when a practice change is actively advocated. In this regard, Alvesson and Kärreman (2011), for example, observe that the pattern language through which research participants express themselves is not only a manifest representation of the reality they are in but also a latent attempt to reconstruct (desired) reality. Therefore, findings from the interview analysis were repeatedly corroborated by reference to the documentary evidence collected in order to distinguish between auditors' latent attempts to promote BDA and manifest representations of actual developments relating to BDA in auditing. Our analytical approach led to the identification of three broad analytical themes that will be subject of discussion in the following section of the paper, namely: (i) the effect of BDA on the nature of relationship between auditors and their clients; (ii) the influence of the 
technology on the execution of the various steps of the audit process; and (iii) the common challenges of embedding BDA in the conduct of the audit.

\section{AUDIT IN A BIG DATA ENVIRONMENT: EARLY EMPIRICAL INSIGHTS}

As mentioned above, the discussion in this section is structured around three empirical themes concerning: first, the implications of the use of BDA for the relationship between auditors and their clients; second, the impact of BDA on the delivery of an audit, including execution of various steps of the audit process from planning to evidence gathering, analysis and reporting; and third, the commonly identified challenges with regards to embedding BDA in the conduct of the audit.

\section{Auditor-client relationship in a data-driven environment}

One of the issues relating to auditor-client relationship in an environment characterized by the rise of Big Data relates to the fact that some audit clients may indeed already experience "deep changes in the modus operandi of management structures, decisions and strategies" (Bhimani and Willcocks, 2014), hence raising questions about the way in which this may, in turn, impact the auditor's approach to gathering evidence in the course of the audit. In this regard, changes in information systems and the manner of use of information to understand, manage and control a business affects the nature of the underlying data available to audit and, if BDA affects strategic business decisions, then this also impacts on the nature of the enterprise that is subject to audit. Audit clients employing technological tools such as ERP, for example, have been said to "have dramatically expanded their traditional data stores, thus keeping large databases in the ERP systems" (Vasarhelyi et al., 2015, p. 385). Such Big Data stores, as has been noted in recent literature, are associated with an "unprecedented level of potential relation to the provisioning of diverse, voluminous datasets and sophisticated analyses", giving rise to questions such as "how data are accumulated and recorded, how management uses data to attain organizational goals, and how reporting elements are processed and assembled" (Warren et al., 2015, p. 397). Our interview analysis suggests the significance of these issues as clients' growing reliance on BDA tools yield opportunities for auditors to process and make sense of the large data sets relating to the clients' business systems. 
We start using functions inherent in financial systems. A good example is SAP ["Systems, Applications, Products" - authors] control framework built which uses functionalities like authorizing invoices. When I first started auditing we had to look at the invoices and make sure someone has signed them. You don't do that anymore. A much better way is to pull a file from the financial system and see how many invoices were not authorized because it is electronic. There are different ways around it, and that is set to develop. [D2]

Furthermore, the clients' growing interaction with Big Data tools, according to some interviewees, leads to the changing expectations as to the kind of audit (and audit evidence) that is appropriate for their business. The following interview excerpt illustrates this point:

If you think of a traditional audit, your data sources are ERP and Financial Systems. However, now clients, stakeholders and others also want to hear about unstructured data, they want you to talk about emails, external data and so on. [D1]

Another particular feature of BDA pointed out in the interviews by auditors is that it improves their ability to communicate the outcomes of the audit in a way which their clients perceive to be more understandable and adding value. By providing an abundant supply of what Earley (2015, p. 3) referred to as "visually appealing analytics to impress clients", BDA is used by auditors to visualise the thought process behind auditor judgement - such as with regards to the identification of key areas of potential risk, hence contributing to higher perceived quality of audit. Specifically, some interviewees pointed out that Big Data supplied by the client and processed within an audit firm environment can facilitate an informed dialogue and comparison between an auditor and the client around issues of risk assessment. Likewise, according to the audit firms' reports, analysis of large data sets can help "highlight behavioral outliers and... direct audit activity toward areas of greatest risk" (Deloitte, 2013, p. 6). Interactive visualisation sessions between an auditor and the client are now common features of audit engagements where often highly complex analytical representations are used to represent information in a way which highlights particular issues that are of concern to the client.

I get access to all those transactions that are the mechanics of how the business works; but for risk assessment, I can summarise all that information up for the client into a single graph, a picture set of analyses. In a sense, [BDA] is taking the transactional information and generating high level information for the auditor to supplement the previous approach to business risk assessment; and the hoped outcome of this is that you have more confidence in your risk assessment. [P1]

We have had some feedback from one of our biggest clients when we first introduced the major piece of analytics into their audit, this probably goes back to four to five years 
now since we first started. They have huge shared service centres and the guy who runs the centres commented at the end, "now we feel like we know what has really been audited this year. [P5]

Many of the auditors interviewed also referred to the role that BDA can play in helping resolve disagreements between clients and their auditors, specifically on areas involving a significant amount of judgement:

If you go to that client [in this case a gas company] and say well, we have checked the last twenty years of data and we have predicted the fine pattern for the next year, or the gas price from all our calculations. There is no way you are going to make revenue $\mathrm{X}$. It is going to be way less, and we think you should impair. That's what it will do. It will give weight of evidence so those professional judgements conversations are based on facts. [P2]

More recently, there is an emerging trend where the significant investment in BDA undertaken by some large audit firms generates interest among their clients seeking to develop systems that use analytics as part of decision-making. For example, auditors' use of analytics in Big Data environments is having an effect on changing the practices and processes clients use to evaluate aspects of employee performance and planning, as illustrated by the following comment from an interview in one audit firm which has developed a financial stress index to measure staff efficiency:

We are now actually finding our clients are asking to use our extraction tools to get their own data into other parts of their business, particularly internal audit. So, that is really interesting and we as external auditors are often better able to give our clients the data they need but, once we have got the technology to do it, we are perfectly happy to allow the company themselves to re-use that technology. What we do not do is give them our analytics because that would be a breach of independence. [P1]

The above interview excerpt shows the efforts of the audit firms to drive their clients towards a greater appreciation of the usefulness of Big Data and BDA to their business. Among other things, some audit firms administer surveys to highlight the areas where clients would require data analytics. In one such survey, one of the Big Four audit firms, called for Big Data to become a board room issue and for the need for business to become "analytics driven organizations to create value" (EY, 2015). Such, mainly self-sponsored, surveys serve as a marketing tool to draw existing clients into the Big Data space and to attract new clients. Importantly, they may also serve to show how the major professional firms seek to become leaders rather than followers in the "Big Data curve". 
The above discussion reveals how BDA is drawn upon by the firms as a basis for broadening the range of services offered to clients, particularly those more advisory in nature, subject to the limits that are imposed by regulation on the joint provision of audit and non-audit services. The manner in which BDA findings are used by firms is therefore relevant to the longstanding debate on whether joint provision can affect the auditor's independence, notwithstanding the increased regulatory constraint of recent years (Earley, 2015). This excerpt from a public report by one of the Big Four firms is particularly revealing in this regard:

We see audit as an opportunity, not an obligation, we go broader and deeper beyond statutory requirements, to realize the value of the data that's available. We help organizations take stock of their financial statement, learn about their performance, understand where they could be doing better, and prepare for what the future may bring [Data and Analytics -Unlocking the value of audit, KPMG, 2014, p. $2^{2}$ ]

The illuminating excerpt above highlights a number of issues. The emphasis on helping organizations to take stock and learn suggests a portrayal of the role of the auditor as someone there to assist the client rather than to act as a watchdog over their financial reporting. From this perspective, the BDA-driven audit process effectively becomes a learning process for auditors as it provides ways to map out the future of the client's business and hence test potential areas for promoting other services. Another excerpt from the same document reinforces this observation: "[w]e can more easily identify trends and anomalies for further investigation. It allows us to give organizations greater insights into their past performance. And this in turn enables them to take stock of their processes and activities and adjust them to improve performance" (KPMG, 2014, p. 4). In addition, the idea that audit is not an "obligation' but an 'opportunity" points to a possible re-conceptualization of the purpose of auditing in the era of data analytics as a function supporting the interest of the client (in unlocking an organization's potential) rather than as a more conventional verification exercise. The critical issue here is the way in which the output from BDA, and the potential insights it offers, can affect the 'mindset' of the auditor, possibly sub-consciously, towards a supportive or consultancy view of the audit itself. The following interview excerpt exemplifies this kind of concern:

\footnotetext{
2 See https://home.kpmg.com/au/en/home/insights/2015/02/audit-data-analytics-unlocking-value-of-audit.html (accessed 30 October 2017)
} 
A big threat with BDA is around independence or perceived independence. We have a technology where once a week we can pull results out for the client, we can produce dashboards for them which show them stuff. [...] The value-added piece of that data gives rise to some real issues as to where do we draw the line and how can we stop the client integrating what we are doing as part of their control process - because they want that kind of insight to come through from us. So, there are real issues around independence here. [D1]

They [clients] can see this is really beneficial for them and we've got clients who ask us, "Can we buy your software?", and the answer is, "No", because this will have an impact on our audit work and independence. [P7]

It also has to be noted however that, whist many audit clients are eager to involve their auditors in exploring the opportunities presented by BDA, there are also those that are less keen on opening up their ERP systems to BDA, pointing to concerns over the motives behind the use of BDA as well as issues relating to data security (Ramlukan, 2015). These client concerns may, in turn, affect auditors' ability to access the data that is relevant to an audit.

[Some] clients are really sensitive to the idea that their information is used in bench marking because they don't want to give away any competitive advantage. [P5]

No matter how easy you make it when you use analytics, the client has to provide you with data. And therefore, if a client doesn't use analytics, perhaps had used analytics with little benefit in the past, or simply is not particularly open to the idea then it can be difficult to use analytics in an audit because the client is not keen to provide the data. [D2]

\section{The implications of BDA for the conduct of an audit}

In recent years, the primary driver for changes in audit approaches and methods has been auditors' stated commitment to improving audit quality (Matthews, 2006; Robson et al., 2007) which has been tainted by corporate collapses where the standard of audit work has been questioned and, more recently, by what is seen as auditors' failure to do enough in the period leading up to the financial crisis (Sikka, 2009). Against this background, it is unsurprising that the audit firms are eager to emphasize the technical opportunities that BDA presents for optimizing the standard of audit delivered to their clients, informing auditor judgement and improving the manner in which judgements are made. The following examples of the audit firms' public communications provide evidence of their efforts to present advanced analytics as an instrument for transforming auditing: 
By combining the leading edge predictive analytics capability of MAT with our own data and analytics expertise, we are set to transform our approach to audit to deliver greater quality, value and actionable insights. (KPMG, 2014, p. 12)

We're excited about data-enabled auditing, and also about new ways of reporting that reflect society's changing expectations of performance and value. (PwC, 2014, p. 7)

The above bold statements inevitably invite questions about the particular areas where BDA is seen as having an especially significant impact on audit conduct. Analysis of our interviews point to two such key areas, namely: (i) organisation of delivery of the audit, and particularly possibilities for further outsourcing audit-related tasks and processes, and (ii) the execution of various steps of the audit process.

With regards to the first point, developments in BDA seem to endorse existing accounts of the data-driven technological innovations in audit as generating greater opportunities for audit outsourcing and making remote auditing a reality (Teeter et al., 2010). Here, the interviewees from audit firms stated that, as a result of BDA tools being used to collect relevant information from their clients' ERPs irrespective of their location, it is increasingly the case that their audit teams do not need to be physically present at the client premises. Furthermore, this increased data availability and mobility has meant that the auditing procedures that are regarded as repetitive (such as re-computations) are now assigned to and performed at centralized shared services centres. Most large firms now have such centres in countries where the level of IT expertise is high whilst labour cost is low.

We are going to have more auditors in India, in the Philippines etc. etc. Because that is where our clients have shared services. It means we [audit firms] are bringing control and delivery of the audit closer to central partner team. [D2]

Some interviewees argued that the outsourcing of mundane audit tasks can free up much needed time for auditors to concentrate on complex issues and concerns that require professional judgement. It is easy to see, however, how these claims may face sceptical reactions from some who point to auditors' emphasis on minimization of the cost of audit to maintain competitiveness.

As regards the execution of auditing steps, our empirical analysis points to a number of technical areas where BDA may be useful to auditors, including those relating to audit planning and risk assessment, evidence gathering, performance of substantive and analytical procedures, among others. These potential impacts stem from a range of unique opportunities presented by 
BDA, for example an enhanced ability to navigate messy data at a faster rate, to identify material exceptions based on the analysis of the whole population, or to fully verify transactions and, if necessary, each individual calculation in areas where significant judgement is involved. Whilst most, especially large, audit firms have already automated their audit process, from client acceptance to record management, BDA tools are adding another dimension by introducing data analytics procedures to the existing automation trail, while at the same time making an audit process traceable through digital footprint. The following interview quotations demonstrate how data analytics tools are utilised in areas of risk assessment:

There is essentially a digitalised map that's telling us for any account balance what are the sources of the numbers that are coming in to that account balance, and therefore, helping us really identify where are the risks within that account balance. [P6]

We have updated our methodology which places much emphasis on how data analytics can be used to support risk assessment with the view to the auditor being able to come up with the classification that means: you've got to do a lot of work, a little bit of work or pretty much no work. And so, we have been building content [and] issue actual guidance to auditors and saying, "If you do this then follow this decision tree, use analytics here, use analytics there, use other procedures there". [P1]

The above comments suggest that, through BDA, the firms appear to be pursuing a progressively more structured approach where the execution of audit tasks is automated and auditors are encouraged to draw on predesigned templates. This is somewhat different from, for example, Business Risk Audit which was motivated in part by a belief that auditors needed to move away from substantive approach involving detailed testing towards a more analytical approach where professional judgement is given prominence (Curtis \& Turley, 2007).

Further, one implication of BDA for the delivery of audits commonly discussed in the interviews concerns audit evidence gathering, both in terms of the nature of evidence collected and its volume. Indeed, Big Data can, at least in principle, refer to a variety of unstructured information relating to company performance that can be used in conjunction with traditional audit evidence to support judgements and decision making. BDA tools may also lead to wider audit scope by making possible full population testing and more detailed analysis of accounting populations. Auditors appear to be making efforts to link BDA to both operational scope and depth, i.e. the two elements that, according to Power (1997, p. 18), constitute sufficient audit evidence. 
As regards the operational scope of the audit and the volume of transactions to be tested, auditors noted that BDA is providing a wider coverage of transactions and even an ability to look at entire populations of journals as opposed to a few items, hence potentially addressing some of the limitations of techniques such as statistical sampling in providing adequate coverage of the client's business.

Analytics can move you from haphazard sampling [...] to statistical sampling [..] the amount of audit effort is unchanged. I think we would all agree [that it] is more statistically valid in terms of the outcomes you would achieve at the end when the data volumes are large.[...].It is absolutely $100 \%$ transactions as opposed to some cursory examination by eye which just is not practical beyond a few thousand. So, that is quite dramatically different. [P1]

[BDA] is allowing the auditor to slice and dice the segments of the journals they care about in order to underpin a particular financial balance they are trying to audit. And on the back of that, and that's the analytical input they are now doing, [they are able] to say, "What do I know about the business, what the management said and what I think?", "What might be going in the industry around this topic?", and collectively bring all that together and conclude on their risk assessment. So, this is how you can do more with the journals. [P5]

Furthermore, with respect to operational depth which refers to the amount of tests that can be performed on the transactions (Power, 1997, p.18), auditors pointed out that the prevailing approach has been to apply BDA tools that largely reflect the existing traditional audit procedures that were previously administered manually - such as re-computations, recalculations, or reconciliations - rather than using such tools to develop qualitatively different procedures.

Another area is re-computation, there are areas within financial statements that are systemically generated by the client and, as a consequence, we can systemically test them. So, a classic example is depreciation interest calculations and certain aspects of provisioning. Historically, the auditors would do either a test to say "does the maths seem to be working" or do what is known as rationalization. [P2]

Whilst these practices do not produce analytical procedures that can be unequivocally attributed to the rise of BDA, it is plausible that they serve as 'legacy practices' (see Power, 2003) to soften possible resistance to a more comprehensive rollout of BDA tools in the future and to ensure smooth transition. As is evident from the recent overview by the Financial Reporting Council (FRC) of the use of analytics in auditing (FRC, 2017), journal testing is the most common area where data analytics tools are used. This can be attributed to the regulatory 
requirement contained in ISA 240 that auditors demonstrate greater rigour in evaluation of fraud risk factors. From this perspective BDA is seen here as a means to meet the regulatory imperative in areas of public concern. The interview excerpt below further illustrates this point:

Audit needs to satisfy the FRC needs, so we communicate with them about what we have done and why to give comfort that we have covered for big risks. Journal testing has been called out as poor across all the Big Four, it has been called out as too formulae and that not enough thought has gone into what are the highest risk journals. We use analytics now to document the process, and rather than picking a random sample size, the tool lets you filter down to focus on small number of high risk journals. So the sample is chosen based on risk, which is a much better way of auditing. So data analytics is helping to make sure we don't get any deficiencies around journals. [D2]

While the interview evidence cited above points to a growing reliance on data analytics tools in the audit process, it is less clear whether these developments can or should be taken as a sure sign that auditors are now operating in "Big Data" environments. This skepticism is shared by the auditors themselves, with some of our respondents voicing an opinion that the amount of transactions that auditors analyse remains small, and so they effectively leave unexplored much of information that is labelled as Big Data. They argued, for example, that the use of social platforms such as Facebook and Twitter has, at least at present, little place in the conduct of the audit, which appears to contradict prior suggestion by some commentators that the resources available on such social platforms could transform the way audits are conducted (see, for example, Cao et al., 2015). The following comments by an audit partner and a director from Big Four firms capture this sentiment:

I don't believe [in Big Data]. For me there is this notion of Big Data but we are nowhere near it in our organization and our business. Big Data is people like Facebook, Google - that is not us. We are not those people. [P1]

If you think an audit as material misstatements and looking at assertions over financial statements, clearly social media is not directly impacting any of those. [P4]

Likewise, our empirical analysis indicates that, despite some innovations such as incorporating google maps facility into procedures to verify assertions relating to travel expenses or utilizing large social data stores to establish quantifiable indicators of highly subjective categories such as national culture which has been adopted in one of the Big Four firms, it is still premature to make claims about BDA having a transformational effect on the nature of audit evidence in a conventional audit engagement. 
Our interviewees point out that audit firms' inability to roll out BDA to wider elements of the audit process has much to do with a lack of required competence and expertise among auditors. The firms' senior representatives interviewed commented that their staff are more often than not ill-equipped to deal intelligently with large amounts of information, and commonly face challenges from information overload and the difficulties of distinguishing relevant information (Earley, 2015; Krahel and Titera, 2015)). The large majority of auditors, including those from large firms, do not possess computer programming skills that could instruct BDA to perform various audit tests. As a consequence of such knowledge shortages, the promotion and operationalisation of BDA tools in auditing is often facilitated, and sometimes controlled, by specialists such as data scientists who have little to do with the conduct of an audit, with auditors playing the role of consumers rather than developers of their firms’ BDA capabilities.

We need people who are a lot more literate in using data. So, if you've got pilot data that you want to use, you will have to identify and think about it in terms data fields, data groups, data bases, how they can be appended, how they can be cleared, exactly which data fields you need to put into whatever form you are using, and how that all can be manipulated. A lot of those principles come with reasonably advanced excel usage and also knowledge of tools such as IDEA, SQL, and others. [D1]

Our interview evidence suggests, however, that the auditors are acutely aware of the need to retain control over the application of data analytics and effectively to be able to operate almost as data specialists themselves. Recognizing this point, major firms have undertaken significant investment in the establishment of the so called architecture for analytics, at both local and global network-levels, running their own training programmes and establishing external collaborations to develop highly skilled in-house analysts. KPMG, for example, in co-operation with Imperial College London, has established a £20m Centre for Advanced Business Analytics focused "on developing fresh approaches to working with large, ambiguous and complex data sets and translating it into potential solutions by developing new tools, methods and techniques to harness the power of big-data"3.

\section{Challenges with embedding BDA tools}

See http://www.imperial.ac.uk/business-school/research/kpmg-centre-for-advanced-business-analytics/ (Accessed 21 $1^{\text {st }}$ September 2015). 
As regards the practical application of BDA tools in the audit context, the common concern among the auditors is that the testing of entire populations enabled through these tools can often highlight outliers that are regarded in an audit jargon as "false positives", which implies that BDA might generate evidence that suggests a concern requiring auditor's attention, when the opposite is in fact true. One possible consequence therefore is that an inappropriate assessment of the sufficiency of audit evidence could lead to over-auditing (Barnes, 2004). Outliers, regardless of whether or not they are false positives, often lead to an increased volume of work auditors have to do and hence higher costs for the audit. Given that BDA is often promoted on the basis of cost savings it could bring to the audit, some interviewees warned that the presence and prevalence of false positives reduces the likelihood of BDA being embedded in the audit process.

The principle or objective if you like of this platform is to deliver analytics in a costeffective way into all of our audits without consideration of the ability of the auditee to pay. So, all our clients from top to bottom have access to quality analytics irrespective of whether they are big or little clients. [P1]

In one interview, a case was cited where the presence of false positives in one particular engagement created tensions between the engagement partner and a data analytics partner, where the engagement partner was concerned about the strain on the audit budget because more work was expected to be done on the outliers which could later prove to be false positives. As the Data Assurance Partner recollects,

I made a couple of audit partners very grumpy as they had to do additional procedures to just confirm that the things I had found [through the use of BDA] wouldn't adjust their audit opinion. The good news was that it didn't adjust their audit opinion. [P7]

Other interviewees suggested that an auditor's over- (or under-) reliance on BDA outputs may be a function of their level of confidence and experience. In particular, where auditors are not comfortable with the audit procedures performed by BDA, they may opt for repeating those procedures using traditional methods.

The reality is we could not get them [audit team members] to stop doing the manual things that they have been trained to do, so they ended up doing all the manual things even though we did all the data analytics, and then they didn't have any time to do the exciting stuff. [P7]

You do often find an auditor will use analytics but will be asked by the senior person to also do the traditional audit techniques, which will lead to double the work. [D2] 
The question [auditors have] is "What is it actually going to bring to my audit other than cost me a lot of money?". So, it's been a battle to say, "Yes, you did do analytics before but if you run these tests over payroll you get a lot more comfort and the quality of your audit will improve". [M3]

Another set of concerns relates to the evident tensions between auditors and data scientists as regarding their role for embedding BDA into daily audit processes and routines. Historically, auditors have relied upon experts from other fields as part of the process of arriving at professional judgements (see Power 1997; O’Dwyer et al., 2011). While the same can be said about data analysts, the level of influence these specialists have in some audit firms seems to go well beyond what would otherwise be expected of an expert external to audit. Many auditors interviewed for this study point to data analysts being involved in the execution of key audit steps, such as audit planning through design of computer scripts to extract data for initial risk assessment, or performing tests such as re-computation or re-calculation to produce a report about the clients' systems for use by auditors. Here, auditors rely on data analysts to provide them with an understanding of the client's business. Further, in some firms interviewed, the data analysts, through their lead partner, sign off any reports generated through BDA before they can be used by the audit teams. This suggests that the construction of audit evidence is coproduced between auditors and data analysts, thereby reconfiguring how sufficient audit evidence is derived.

We are already seeing that audit teams include more data analytics people; thus, people can understand the database structures and data field. We have got different levels, we have got foundational people, they are the architects, they understand how to take client data and turn it into useable formats. [M3]

There is also evidence that, in some instances, data analytics teams are responsible for selecting BDA tools to be used by auditors, which creates tensions with audit team members who maintain that the selection of audit toolkits should be left to auditors themselves.

I think, historically, [data scientists] have been seen very much as a support service, sort of 'where I don't want to do journals testing, you do that, send my report back and I will review the exceptions'. I think now they can no longer be seen as a support service. They are an integral part of the actual audit team. [...] So, the data group sit with the audit team, they are part of the audit team, they work very closely with them. [M3]

Fundamentally, we need to put analytics into the hands of the auditors as opposed to the specialists because the specialists are an expensive resource and they are finite resource, and the model could only deliver it to the biggest, most prestigious clients. [P5] 
Furthermore, a potentially significant obstacle to a more widespread use of BDA, according to some interviewees, is the fact that the issue so far has not been specifically discussed in the auditing standards. While some auditors perceive this lack of guidance as an opportunity to innovate without worrying about possibly substantial regulatory restrictions, others commented that they would refrain from fully engaging with BDA unless the standard setters eliminated what they see as uncertainties around BDA use. Such views by auditors echo earlier discussion by commentators such as Cao et al. (2015) who argue that the modern auditing standards do not provide sufficient opportunity for BDA to be fully exploited in the conduct of an audit, and called specifically, for the revision of a number of international auditing standards ${ }^{4}$.

In contrast, our discussions with members of the standard setting community conducted for this study, particularly from the IAASB that develop ISAs, suggest that the standard setters do not share the above views. Some of them argued, for example, that current auditing standards are flexible enough to permit the exploitation of BDA in the audit context, although it is also evident that concerns do exist over the way in which the introduction of BDA may lead to a reconceptualization of aspects of auditing, such as the understanding of materiality and risk factors. While it is generally acknowledged that access to large data can help auditors towards, for example, increasing confidence levels (and lower materiality), it may also have a significant bearing on the way some risks are classified and managed in the course of an audit engagement. This suggests that standard setters prefer to tread carefully before incorporating into standards recognition of BDA developments which one member of the IAASB's Data Analytics Working Group characterized as being in their 'infancy'. The prevalent view is that, at least at present, there is no need to contemplate changes in the current auditing standards as the existing versions provide sufficient scope for auditors to experiment in relation to BDA.

The current audit model is not broken, and has served stakeholders well in the past. It has however been constrained by technological limitations that no longer exist. Additionally, auditors find challenges in fitting the audit evidence derived from data analytics into the current audit approach required by the auditing standards. (Minutes of a meeting of the IAASB's DAWG, 2015).

So, we are not seeing data analytics being used as much as we were expecting it to be. I suppose, in a way, we have been seeing some data analytical tools being used for a long time, particularly around the testing of journals, and so we see in

\footnotetext{
${ }^{4}$ Specifically, the authors mention ISA 315 Identifying and assessing the risks of material misstatement through understanding the entity and its environment, ISA 240 The auditor's responsibility relating to fraud in an audit of financial statements, and ISA 540 Auditing accounting estimates, including fair value accounting estimates, and related disclosures
} 
the audit files that this is pretty much what audit teams are using those tools for. [R4]

The question is as regulators we need to look at how auditors have used those analytics. You said in the audit report that's what you have done. We will then look at the audit file and one of the things we do in our inspections is consider how accurate these descriptions in the audit reports are. Are they really truly reflecting what it is that the audit team has done? So, yes firms are starting to put it [claims about the use of BDA] into their audit reports more but the thing we are concerned about is how fair is that representation? [R2]

\section{BDA AND THE FUTURE OF AUDITING: CONTEMPLATING A RESEARCH AGENDA}

The previous section has provided insights into the application of BDA in auditing as conducted by public practice accounting firms. This view of developments in BDA points to a wide range of issues and concerns which warrant further empirical investigation and critical assessment. In this section, we reflect on those issues in order to set out an agenda for future research that can provide both an in-depth empirical understanding and a theoretical delineation of the impact of BDA on audit work as well as the role and practice of contemporary auditing, more generally. We suggest at least three distinct analytical lenses through which to explore the developments in BDA, namely: technical, economic, and professional, together with examples of particular research questions that warrant in-depth investigation and analysis (for an overview, see Table 3).

From a technical viewpoint, we should consider BDA in auditing in terms of its impact on actual audit procedures, and in particular its capacity to provide a means to enhance audit quality. Prior studies reveal a range of views on audit quality. On the one hand, there are studies supporting a functionalist view that portray quality as a market-derived assessment of auditors' ability to detect material misstatements and report them to relevant stakeholders (see DeFond \& Zang, 2013) for a summary of this literature). On the other hand, we see a growing appreciation among audit scholars (Holm \& Zaman, 2012; Khalifa et al., 2007; Fischer, 1996) as well as regulatory community that "there is no single agreed definition of audit quality that can be used as a "standard"e against which actual performance can be assessed" (FRC, 2006, p. 16; IAASB, 2014). This latter observation resonates with an interpretive perspective on the audit environment and notions of audit quality as a socially constructed phenomenon. Therefore, considering that the use of BDA is a nascent area, researchers could address the 
potential empirical lacuna of how audit quality is conceptualised and operationalised in a datadriven environment. This is important because, while it is possible to identify many potential contributions to audit, we still know relatively little about the extent to which employing BDA is shaping the actual delivery of and outcomes from an audit. For example, it is unclear whether the main impact is simply through greater processing power enabling larger samples but employing essentially the same evidence and test methods, or through the development of genuinely new techniques and use of new forms of evidence. Here, important research questions to be investigated pertain to the extent to which BDA is genuinely reconfiguring the nature of audit evidence through incorporation of data that was previously outside audit consideration but that can be used in a diagnostic way to alert auditors to potential areas of problem in the financial statements. Here, researchers could draw relevant insights from, for example, Power (1997) who provides evidence of how domains previously seen as peripheral and problematic for an audit were made auditable; and also William (2013) who demonstrates how tools such as BDA could be used to construct objects as risky and requiring regulatory attention. Both these studies attend to the social constructivist nature of audit spaces as well as audit evidence as co-produced through interaction between auditors and technology.

There is also a need for empirically grounded work to explore whether BDA is indeed transformational, as is often presented by the audit firms themselves, in the execution of routine audit work and analytical procedures. More specifically, are the benefits of reliance on BDA mainly associated with the power of processing and resulting opportunities to increase the coverage of data sets subject to investigation or with the use of new, innovative analytical procedures in the course of an audit? Here, there is a question of both motivation and actuality - that is the reason behind auditors' attempts to engage with the Big Data environments may well be motivated by rationales of improving the standard of audit but, given prior research findings about the difficulties of implementation of methodological developments (see, for instance, Curtis and Turley, 2007), questions should still be raised about the impact of such efforts on actual audit practice.

Further, in understanding the technical aspects of the application of BDA in the audit context, there is also a need to account for the manner in which the growing significance of data processing technologies may be shaping the very nature of what auditors do (William, 2013). A more technologically enhanced BDA audit process, and a more technologically aware auditor, may indeed be presented as necessary for auditors to be able to operate successfully in the modern business environment. However, we call for research that can penetrate through 
this technocratic image and question underlying assumptions, such as those about the role of judgement and structure in audit work (Power, 2003). It has been observed that technologies that are designed to offer guidance to auditors in making professional judgements can often produce an opposite effect. Dowling et al. (2008), for example, find that auditors who had adopted a very prescriptive decision support system identified fewer business risks than those who used a less prescriptive approach. They suggest, in particular, that a "hard" structured approach encoded in the new technology could limit the cognitive ability of auditors to generate many cues for assessing audit risks associated with the business. For years, a mystery surrounding what auditors do has enabled them to encourage a perception of a judgementintensive practice that warrants higher fees. On the one hand, there is a possibility that the push for BDA is in conflict with that ambition, potentially leading to predominantly routinized and increasingly technique-based approaches to audit which minimize the need for professional judgement. On the other hand, however, one can also make a counter argument that the additional insights generated through the use of BDA tools need to be made sense of and interpreted by auditors, and these sense-making endeavours ultimately require a degree of professional judgment. As we have demonstrated earlier, decisions around false positives, or the nature and veracity of data brought to an auditor's attention through the use of BDA are examples of areas that bring to the fore the issues round rationalisation and inference.

As the practice potentially spreads and both the rhetoric and actuality of BDA becomes more prevalent, there is also a need to examine the extent to which these developments are accommodated in existing generalized regulatory standards or challenge such standards. The relationship between innovation in firm methodology and the development of generalized standards for auditing is complex (see Curtis et al. (2016) on the embedding of BRA in auditing standards), reflecting the fact that standards need to provide some latitude for interpretation and innovation and also to be seen to be relevant to up-to-date developments in practice, but that standard-setters do not want simply to follow an agenda set by practice firms (Bamber \& McMeeking, 2016). The potential for distance between formal standards and day-to-day practice in respect of BDA in auditing is relevant not only for standards setters, as included in the IAASB 2015-16 work plan (IAASB, 2014), but also from a research perspective. Therefore, there is an important role for in-depth empirical research that could produce understandings to inform and provide a direction for auditing standard-setting agendas.

From an economic viewpoint, our findings demonstrate that the employment of BDA can be seen as relevant to the 'business of auditing', potentially affecting audit costs and the 
efficiency of audit work. Here, there is a need for a more critical assessment of whether the firms' representation of BDA as the next big thing in the development of audit practice is driven, at least to a certain degree, by their strategies for business expansion and the competitive rationales where BDA may be used as a tool for further differentiation and segregation between the large and smaller audit firms, for example because of the necessary investment in technology and expertise. The latter could struggle to achieve the level of investment in training and development necessary for the application of complex BDA tools. Economic motivations behind the rise of BDA should constitute an important research agenda that could shed light on the extent to which the penetration of BDA into auditing is not only a consequence of the audit clients' changing business realities but also a product of the firms' pursuit of their own strategic agendas.

Moreover, the quest for further business opportunities to be exploited in an era of BDA is likely to be affecting the fluidity of the boundaries between audit and consultancy (Robson et al., 2007; Jepperson, 1998). Prior audit literature provides ample evidence of audit firms' efforts to expand their services into new, often consultancy-oriented activity domains (Andon et al., 2015; Shafer \& Gendron, 2005) by pursuing an image of auditors as 'versatile experts' (Guo, 2016, p. 100) who can withstand the competitive nature of the audit field while also upholding the normative values of the profession. Similarly, given the scale of investment required in the process of developing and maintaining BDA algorithms, software and tools, it is unlikely that auditing alone can generate sufficient resources to support the necessary investment and the auditor will, as a result, end up using analytical tools which have been created to serve the needs of the firms' other service lines. The BDA tools themselves may therefore not reflect purely an audit mindset. The danger here is that of a more client service mindset regarding the underlying purpose and justification of the audit. This is something that goes to heart of what might be called auditors' 'self-worth', that is how they perceive the value of the activity they undertake and its connection to something valued by management and the board. Several important questions should be investigated here. What are the consequences of BDA for the standing of auditing in a multi-disciplinary multi-service audit firm context? What is the potential contribution of BDA to the marginalization of auditing within the major firms' service portfolios? Can the rise of BDA result in shifts in the perceived role of the audit service as primarily a supplier of knowledge spill-overs and business opportunities for the firms' other service lines? 
Lastly, the obvious and highly significant consequence of BDA research should consider is for the notions of accounting professionalism. Specifically, audit scholars should contemplate the manner in which auditors' efforts to be seen as possessing the expertise and knowledge required for BDA environments are potentially altering the nature of skillsets and competencies attributed to a modern-day auditor and, more fundamentally, even his/her professional identity. The issue about how exactly encounters with BDA may be changing the notion of auditor expertise, knowledge and identity is an important one. If the skills required of modern auditors become skewed towards more technical, "number-crunching" types of competencies, this would have implications for the manner in which practice provides a suitable environment for the development of auditors as professionals (Turley et al, 2016), The use of the term "data scientist" is becoming more common place in auditing, which suggests auditors' preference to imagine themselves as sophisticated experts, at least as far as data processing and analysis is concerned. However, it is not clear that mastering more quantitatively oriented skillsets leads to better auditors and better auditor judgements. Power (1995) encourages us not to assume auditor's expertise as given but as (co-) produced. Again, a number of possible significant research questions can be suggested. What is the influence of the spread of BDA on the knowledge base auditors draw on? How do encounters with large datasets impact auditors' ability (and perceived need) to develop more inference-type skills that are commonly attributed to professionals as against other occupational groups? What are the consequences of BDA for auditors' self-image as well any changes in personal and professional attributes that make up their identity at work? And ultimately, can the rise of BDA potentially generate significant de-skilling effects on accounting labour?

These latter concerns about the potential "de-professionalizing" effect of highly technically oriented work environments are not unfounded and have already been voiced in the professionalization literature. Abbott (1988), for example, emphasized how reliance on mathematical techniques potentially dilutes professional systems of knowledge and diminishes the image that professionals create for themselves, because it is primarily on the basis of their expert knowledge that professions build their jurisdictional authority, legitimacy and public image. In the audit context, Omoteso and colleagues (2010) state that automated audit technologies have the capacity to change the organisational structure of audit firms as some tasks previously performed by auditors are taken over by the technology, implying a deskilling effect of such changes on audit professionals (see Dowling et al. (2008) for a similar view). Power (1997) raised similar concerns when arguing that if the idea behind the rise of statistical 
audit sampling was a project to construct and codify auditors' knowledge base then the outcomes were somewhat mixed. It is relevant to raise these points with respect of the current situation with the rise of BDA in auditing. Indeed, is it possible that history will judge BDA as a destructive innovation, at least in terms of the standing of auditing and auditors as a professional group? With driverless cars being seen only recently as a product of fictitious mind, will we ever see an 'auditorless' audit?

In conclusion, taking these possibilities together it can be argued that, just as in case of many other technological developments in auditing over the past several decades (Humphrey \& Moizer, 1990; Power, 1992; Carpenter \& Dirsmith, 1993; Robson et al., 2007; Curtis \& Turley, 2007), auditors' recourse to technical development should be assessed not only from the point of view of the technical improvements to practice but also in terms of their more fundamental relevance to understanding the significance and role of auditing in the governance of business. There is an underlying question whether, as has been the case with other methodological developments previously, BDA developments reflect auditors' search for a technical solution to what essentially are existential problems and dilemmas facing the audit profession that, among other things, have to do with issues such as the societal relevance of the audit function, the continuing expectations gap and auditors' ability as knowledge experts to meet the complexity inherent in contemporary financial reporting practice. Certainly, there is a danger of disappointment if BDA developments are seen as the golden ticket which is going to solve audit problems and lead to a future in which audit services are universally valued. Equally however, these developments may provide real tools to reconfigure, refocus and potentially reposition (within the firms' business models) contemporary audit practice and, because of such potentially significant transformative effects, should be subject to much higher level of scholarly attention and debate.

\section{References}

Abbott (1988), The system of professions. The essay on the division of expert labour. University of Chicago Press, Chicago, USA.

ACCA (2015), Big data audit dynamite. Association of Chartered Certified Accountants, London, UK.

Accountancy Futures Academy (2013), Big data: its power and perils, Association of Chartered Certified Accountants, London, November.

AICPA (2014), Reimagining auditing in a wired world, NY New York http://www.aicpa.org/InterestAreas/FRC/AssuranceAdvisoryServices/DownloadableDo cuments/Whitepaper Blue Sky Scenario-Pinkbook.pdf 
Alles,G.M.(2015), Drivers of the use and facilitators and obstacles of the evolution of Big Data by the audit profession, Accounting Horizons, Vol.29, No.2, pp.439-449.

Alles, G.M and Gray, G.L (2016), Incorporating Big Data in audits: Identifying inhibitors and a research agenda to address those inhibitors, International Journal of Accounting Information system, Vol.22,pp.44-59.

Alvesson, M., and Karreman, D. (2011), Qualitative research and theory development: Mystery as method. London, Sage Publications .

Andon, P., Free, C. and Sivabalan, P. (2014), The legitimacy of new assurance providers: Making the cap, Accounting, Organizations and Society, 39, pp. 79-96.

Andon, P. Free, C. and O'Dwyer, B. (2015) Annexing new audit spaces: challenges and adaptations, Accounting, Auditing and Accountability Journal, Vol. 28, No. 8, pp.1400 $-1430$.

Appelbaum, D., Kogan, A., and Vasarhelyi, M.A. (2017), Big Data and analytics in the modern audit engagement: research needs, Auditing: A Journal of Practice and Theory, Vol. 36, No. 4, pp. 11-27.

Arnaboldi, M., Busco, C., and Cuganesan, S. (2017), Accounting, accountability, social media and big data: Revolution or hype?, Accounting, Auditing and Accountability Journal, Vol. 30, No. 4, pp. 762-776.

Bamber, M. and McMeeking,K. (2016), An examination of international accounting standardsetting due process and the implications for legitimacy, British Accounting Review, Vol.48,No.1,pp 59-73.

Bamber, E.M. and Snowball, D. (1988), An experimental study of the effects of audit structure in uncertain task environment, The Accounting Review, Vol.63, No.3, pp. 490-504.

Barnes,PA (2004), The auditor's going concern decision and Types I and II Errors: The Coase theorem,transaction Costs, bargaining power and attempts to mislead, Journal of Accounting and Public Policy, Vol.23, No.6,pp415-440.

Bartram,P. (2013), The value of data, Financial Management, Chartered Institute of Management Accountants, London, March, pp.26-31.

Bhimani, A., and Willcocks, L. (2014), Digitisation, 'Big Data' and the transformation of accounting information, Accounting and Business Research, Vol. 44, No. 4, pp. 469-490.

Brown-Liburd, H., Issa, H. and Lombardi, D. (2015), Behavioral implication of Big Data's impact on audit judgment and decision making and future research directions, Accounting Horizons, Vol.29, No.2, pp. .451-468.

Bi, Z. and Cochran, D. (2014), Big data analytics with applications, Journal of Management Analytics, Vol.1, No.4, pp. 249-265.

Cao.M., Chychyla, R. and Stewart, T. (2015), Big Data Analytics in Financial Statement Audits, Accounting Horizons, Vol.29, No.2, pp.423-429.

Carpenter, B., and Dirsmith, M. (1993), Sampling and the abstraction of knowledge in the auditing profession: An extended institutional theory perspective, Accounting, Organizations and Society, Vol.18, No.1, pp. 41-63.

Chen ,H., Chiang, R.H.L., and Storey, V.C. (2012), Business intelligence and analytics: From Big Data to big impact, MIS Quarterly, Vol.36, No.4, pp.1165-1188.

Curtis,E.,Humphrey, C. and Turley,S.W.(2016),Standards pf Innovation in Auditing, Auditing: A Journal of Practice \& Theory, Vol.35,No.3, pp. 75-98

Curtis, E. and Turley, S. (2007), The Business Risk Audit: a longitudinal case study of an audit engagement, Accounting, Organizations and Society, Vol. 32 No.4-5, pp.439-461.

Cushing, B. E., and Loebbecke, J. K. (1986), Comparison of audit methodologies of large accounting firms, American Accounting Association, Sarasota, Fla.

Deloitte (2014), Audit Transparency Report for the year ended 31 May 2014, Deloitte LLP, London. 
Department for Business, Innovation and Skills (BIS) (2013), Seizing the data opportunity: A strategy for UK data capability, Department for Business, Innovation and Skills, London.

DeFond, M. and Zhang,J. (2014), A review of archival audit research, Journal of Accounting and Economics, Vol.58,Nos.2-3,pp275-326.

Dirsmith, M.W and Haskins, M.E. (1991), Inherent risk assessment and audit firm technology: a contrast in world theories, Accounting, Organizations and Society, Vol.16, No.1, pp 61-90.

Dowling, C., Leech, S. A., and Moroney, R. (2008), Audit Support System Design and the Declarative Knowledge of Long-Term Users. Journal of Emerging Technologies in Accounting, Vol.5, No.1, pp.99-108.

Earley, C.E. (2015), Data analytics in auditing: Opportunities and challenges, Business Horizons (in press)

Elliott, R.K. and Jacobson, P.D. (1998), Audit independence concepts, CPA Journal, Vol. 68 No. 12 , pp. 30-33

EY (2014), Transparency Report 2014, Ernst and Young Global Limited, United Kingdom.

EY (2015), Becoming an analytics driven organization to create value, Ernst and Young LLP with Nimbus Ninety, London. Available at: http://www.ey.com/UK/en/Services/Specialty-Services/Big-data---Becoming-ananalytics-driven-organisation-to-create-value

Fischer, M. J. (1996), Real-izing the benefits of new technolo- gies as a source of audit evidence: an interpretive field study. Accounting, Organizations and Society, Vol.21,pp. 219-242.

FRC (2006), Discussion Paper Promoting Audit Quality. London: Financial Reporting Council.

FRC ,(2017), Audit Quality Thematic Review: The use of Data Analytics in the Audit of Financial Statements, Financial Reporting Council Limited, London.

Gandomi, A. and Haider, M. (2015), Beyond the hype: Big data concepts, methods, and analytics, International Journal of Information Management, Vol.35, No.2, pp.137-144.

Gartner (2012), IT Glossary - Big Data. Available at http://www.gartner.com/it-glossary/bigdata/ (accessed on 10 May 2015)

Gendron, Y. (2009), What Went Wrong? The Downfall of Arthur Andersen and the Construction of controllability. Boundaries Surrounding Financial Auditing, Contemporary Accounting Research, Vol. 26, pp. 987-1027.

Guo, K.H, (2016), The Institutionalization of Commercialism in the Accounting Profession: An Identity-Experimentation Perspective. AUDITING: A Journal of Practice \& Theory, Vol. 35, No. 3, pp. 99-117.

HM Treasury (2014), Budget 2014, HM Treasury, London. Available at https://www.gov.uk/government/uploads/system/uploads/attachment data/file/293759/ 37630 Budget 2014 Web Accessible.pdf (accessed on 18 May 2015)

Hansen, J.V. and Messier Jr. W. F. (1986) A knowledge-based expert system for auditing advanced computer systems, European Journal of Operational Research,26,371-379

Higson,A.W. (2003), Corporate Financial Reporting:Theory and Practice,London.Sage Publication.

Holm, C. and Zaman, M. (2012), Regulating audit quality: Restoring trust and legitimacy,Accounting Forum, Vol.36,No.1,pp.51-61.

Holstrum,G.L. and Kirtland,J.L. (1983), 'Audit Risk Model: A Framework for current practice and future research ', in Schultz and Brown (eds), 267-309.

Humphrey, C. and Moizer, P. (1990), "From techniques to ideologies: An alternative perspective on the audit function", Critical Perspectives on Accounting, Vol.1, No.3, pp. $217-238$. 
Humphrey, C, O'Dwyer, B \& Unerman, J 2017, Re-theorizing the configuration of organizational fields: The IIRC and the pursuit of 'enlightened' corporate reporting, Accounting and Business Research, Vol. 47, No. 1, pp. 30-63.

IAASB (2013), The IAASB's Proposed Strategy and work program for 2015-2019. Consultation paper, International Auditing Assurance Standards Board, New York.

IAASB (2014a), Work Plan for 2015-2016: Enhancing Audit Quality and Preparing for the Future. Available at: https://www.ifac.org/system/files/publications/files/IAASB-WorkPlan-2015-2016.pdf

IAASB (2014b), A Framework for Audit Quality: Key Elements that Create an Environment for Audit Quality. Available at: https://www.ifac.org/publications-resources/frameworkaudit-quality-key-elements-create-environment-audit-quality

Jeppessen, K. K. (1998). Reinventing auditing, redefining consulting and independence. European Accounting Review, Vol.7,No.3,pp. 517-539.

Knechel, R. (2007), The Business Risk Audit: Origins, Obstacles and Opportunities, Accounting Organisations and Society, Vol. 32, pp. 101-29, 2007.

KPMG. (2014a), UK Annual Report (Including the Transparency Report), KPMG LLP, United Kingdom.

KPMG.(2014b), Data \& Analytics : Unlocking the value of the data. Available at https://www.kpmg.com/Global/en/services/Audit/Documents/unlocking-the-value-ofaudit.pdf (accessed on 15 September 2015)

KPMG (2015) Going beyond the data - turning data from insights to value. Available at: https:/home.kpmg.com/xx/en/home/insights/2015/06/going-beyond-the-dataturning.html

Khalifa, R., Sharma, N.,Humphrey, C. and Robson, K. (2007), Discourse and audit change: Transformations in methodology in the professional audit field, Accounting, Auditing and Accountability Journal, Vol. 20,No. 6, pp.825 - 854

Krahel, P.J. and Titera, W.R. (2015). Consequences of Big Data and formalization on accounting and auditing standards, Accounting Horizons, Vol.29, No.2, pp. 409-422.

Lemon, W.M., Tatum, K.W and Turley, W.S. (2000), Development in the audit methodologies large accounting firms, ABG Publications, London.

MacLullich, K.K. (2003), The emperor's "new" clothes? New audit regimes: Insights from Foucault's technologies of the self. Critical Perspectives on Accounting, 14(8),791-811

Matthews, D. (2006), A History of Auditing: The changing process in Britain from the nineteenth century to the present day. Routledge, Oxford.

Miles, M. B., and Huberman, A. M. (1994). Qualitative data analysis: an expanded sourcebook. Thousand Oaks, Sage Publications

Newton, J.D. and Ashton ,R.H. (1989), The association between audit technology and audit delay, Auditing: A Journal of Practice and Theory, Vol.8, No.2(supplement), pp. 22-37.

Omoteso, K., Patel, A., and Scott, P. (2010), Information and Communications Technology and Auditing: Current Implications and Future Directions. International Journal of Auditing, Vol.14,No.2,pp, 147-162.

O'Dwyer, B., Owen, D. and Unerman, J. (2011), Seeking legitimacy for new assurance forms: the case of assurance on sustainability reporting, Accounting, Organizations and Society, Vol. 36 No. 1, pp. 31-52.

O'Leary, D. E. and M. L. Markus. (2006), Microsoft's management reporting: SAP, data warehousing, and reporting tools. Journal of Emerging Technologies in Accounting, Vol.3,pp, 129-141

Power, M. (1992), From common sense to expertise: The pre-history of auding sampling, Accounting, Organisation and Society, Vol.17, No.1, pp. 37-62. 
Power, M. (1995), “Auditing, Expertise and the Sociology of Technique”, Critical Perspectives in Accounting, Vol. 6, pp. 317-339.

Power, M. (1997), The Audit Society :Rituals of verification. Oxford University Press ,New York,NY.

Power, M. (2003), Auditing and the production of legitimacy, Accounting, Organizations and Society, Vol.28, No.4, pp. 379-394.

PwC (2014a). Building trust through Assurance: Transparency Report, PricewaterhouseCoopers LLP. Available at http://www.pwc.co.uk/transparencyreport/assets/pdf/transparency-report-fy14.pdf (accessed on 27 May 2015).

PwC (2014b), Data analytics delivering intelligence in the moment. PricewaterhouseCoopers LLP, London.

Ramlakun, R. (2015), How Big Data and analytics are transforming the audit. Ernst and Young Global Limited, April, Vol.9, pp. 9-12.

Robson, K., Humphrey, C., Khalifa, R. and Jones, J. (2007), Transforming audit technologies: Business risk audit methodologies and the audit field, Accounting, Organizations and Society, Vol.32, No.4-5, pp. 409-438.

Shafer, W.E. and Gendron, Y., (2005). Analysis of a failed jurisdictional claim: the rhetoric and politics sur- rounding the AICPA global credential project. Accounting, Auditing \& Accountability Journal, Vol.18 ,No.4, pp.453 - 491.

Sikka, P. (2009), Financial Crisis and the Silence of the auditors, Accounting, Organizations and Society, Vol. 34, No.6-7, pp. 868-873.

Smith, M. (2015), The White House Names Dr .DJ Patil as the First U.S Chief Data Scientist, White House blog, Available at https://www.whitehouse.gov/blog/2015/02/18/whitehouse-names-dr-dj-patil-first-us-chief-data-scientist (accessed on 02 June 2015).

Suddaby, R., Cooper, D.J. and Greenwood, R. (2007), Trans-national regulation of professional services: governance dynamics of field level organizational change, Accounting Organizations \& Society, Vol. 32 Nos 4/5, pp. 333-362.

Sully,J.M. (1974), Statistical Sampling in Auditing, Journal of the Royal Statistical Society, 23(1),71-80

Turley, S., and Cooper, M. (1991), Auditing in the UK. Institute of Chartered Accountants in England and Wales, Prentice Hall, Hertfordshire.

Turley, W., Humphrey, C., Samsonova-Taddei, A., Siddiqui, J., Woods, M., Basioudis, . I., \& Richard, C. (2016). Skills, competencies and the sustainability of the modern audit. Institute of Chartered Accountants of Scotland.

Vasarhelyi, M.A., Kogan,A. and Tuttle, B. (2015), Big Data in Accounting: An Overview, Accounting Horizons, Vol.29 No.2,pp.381-396.

Teeter, R. Alles, M. and Vasarhelyi, M.A (2010), Remote Audit: A Research Framework, Journal of Emerging Technologies in Accounting, Vol.7,No.1,pp.73-88

Titera, W.R.(2013), Updating audit standard-enabling audit data analysis, Journal of Information Systems, Vol.27, No.1, pp. 325-331

Wang, T. and Cuthbertson, R. (2014), Eight issues on Audit data analytics we would like researched, Journal of Information Systems, Vol.29, No.1, pp. 155-162.

Warren, Jr.J.D., Moffitt, K.C. and Byrnes, P. (2015), How Big Data Will Change Accounting, Accounting Horizons, Vol.29, No.2, pp. 397-407.

Williams, J. W. (2013). Regulatory technologies, risky subjects, and financial boundaries: Governing "fraud" in the financial markets. Accounting, Organizations and Society, Vol.38, Nos.6-7,pp. 544-558.

Yoon, K., Hoogduin, L. and Zhang, L. (2015), Big Data as complementary Audit Evidence, Accounting Horizons, Vol.29, No.2, pp. 431-438. 
Zhang, L. Pawlicki, A,R. McQuilken, D and Titera, W.R. (2012), The AICPA Assurance Services Executive Assurance Technology Task Force: The audit data standards (ADS) initiative, Journal of Information Systems, Vol.26, No.1, pp.199-205.

Table 1: List of interview participants

\begin{tabular}{|c|l|l|l|}
\hline Code & \multicolumn{1}{c|}{ Participant } & \multicolumn{1}{c|}{ Organization } & \multicolumn{1}{c|}{ Role(s) } \\
\hline P1 & Partner-Risk Analytics* & Big Four & BDA development and implementation \\
P2 & $\begin{array}{l}\text { Partner-Global Audit } \\
\text { Methodology }\end{array}$ & Big Four & BDA development and implementation \\
P3 & $\begin{array}{l}\text { Partner-Audit } \\
\text { Methodology }\end{array}$ & Mid-tier audit firm & $\begin{array}{l}\text { BDA development and implementation; } \\
\text { Standards Setting (DAWG) }\end{array}$ \\
P4 & $\begin{array}{l}\text { Partner- Head of } \\
\text { Assurance }\end{array}$ & Mid-tier audit firm & $\begin{array}{l}\text { BDA development and implementation; } \\
\text { Standards Setting (DAWG) }\end{array}$ \\
P5 & $\begin{array}{l}\text { Partner- Audit } \\
\text { Methodology ** }\end{array}$ & Big Four & $\begin{array}{l}\text { BDA development and implementation; } \\
\text { Standards Setting (DAWG) }\end{array}$ \\
P6 & $\begin{array}{l}\text { Partner-Data Analytics } \\
\text { Bat }\end{array}$ & Big Four & $\begin{array}{l}\text { BDA development and implementation; } \\
\text { Standards Setting (DAWG) }\end{array}$ \\
P7 & $\begin{array}{l}\text { Partner-Data } \\
\text { Assurance }\end{array}$ & Big Four & BDA development and implementation; \\
P8 & Partner & Big Four & BDA development and implementation;
\end{tabular}




\begin{tabular}{|c|c|c|c|}
\hline D1 & $\begin{array}{l}\text { Director-Audit } \\
\text { Methodology** }\end{array}$ & Big Four & BDA development and implementation; \\
\hline D2 & Director - Analytics ** & Big Four & BDA development and implementation; \\
\hline $\mathrm{R} 1$ & Director- Inspection * & Regulator & Regulator \\
\hline $\mathrm{R} 2$ & $\begin{array}{l}\text { Head of Audit and } \\
\text { Assurance * }\end{array}$ & Regulator & Regulator; Standards Setting \\
\hline $\mathrm{R} 3$ & $\begin{array}{l}\text { Director of Audit } \\
\text { Quality }\end{array}$ & Regulator & Regulator \\
\hline $\mathrm{R} 4$ & $\begin{array}{l}\text { Audit Quality -IT audit } \\
\text { inspector* }\end{array}$ & Regulator & Regulator; Standards Setting \\
\hline $\mathrm{R} 5$ & Regulator & $\begin{array}{l}\text { Regulator - } \\
\text { Belgium }\end{array}$ & Regulator; Standard Setting \\
\hline M1 & Manager-Audit & Big Four & BDA implementation \\
\hline M2 & Manager-Audit & Big Four & BDA implementation \\
\hline M3 & $\begin{array}{l}\text { Manager-Data } \\
\text { Assurance }\end{array}$ & Big Four & BDA development and implementation; \\
\hline M4 & Manager-Audit & Mid-tier audit firm & BDA implementation \\
\hline A1 & IT auditor & Big Four & BDA implementation \\
\hline
\end{tabular}

* A follow-up interview was conducted with the same participant

** Group interview.

Table 2: Documentary evidence

\begin{tabular}{|c|c|c|}
\hline Type of evidence & Issuing organization & Time period \\
\hline Transparency reports & Big Four & $2013-2016$ \\
\hline $\begin{array}{l}\text { Thematic Reports: Data } \\
\text { Analytics }\end{array}$ & Financial Reporting Council (UK) & 2017 \\
\hline Data Analytics Survey & Big Four & 2014-2017 \\
\hline Data Analytics Research & $\begin{array}{l}\text { Professional Bodies (ICAEW, ACCA, } \\
\text { Accountancy Europe) }\end{array}$ & $2013-2017$ \\
\hline Data Analytics Presentations & Big Four and IAASB & $2015-2016$ \\
\hline Minutes of DAWG & IAASB & 2015-2016 \\
\hline Conference Proceedings & Accountancy Europe (FEE) & 2015 \\
\hline
\end{tabular}


Table 3: Analytical lenses and related research questions

\begin{tabular}{|l|l|}
\hline Analytical lens & Examples of research questions \\
\hline $\begin{array}{l}\text { Technical } \\
\text { ampact of BDA on audit procedures } \\
\text { quality }\end{array}$ & $\begin{array}{l}\text { What is the actual impact of BDA on the delivery } \\
\text { and the reporting of the outcomes of audit? }\end{array}$ \\
$\begin{array}{l}\text { What is the extent to which BDA is genuinely } \\
\text { reconfiguring the nature of audit evidence? }\end{array}$ \\
$\begin{array}{l}\text { Does BDA lead to truly transformational, } \\
\text { innovative analytical procedures, or simply to } \\
\text { increased coverage and enhanced processing of } \\
\text { information subject to audit by means of } \\
\text { conventional techniques? }\end{array}$ \\
\hline
\end{tabular}




\begin{tabular}{|c|c|}
\hline & $\begin{array}{l}\text { Is BDA associated with more structured, } \\
\text { routinized, and technique-oriented audit } \\
\text { approaches? If so, what is the potential impact of } \\
\text { the rise of BDA on the exercise of professional } \\
\text { judgement by auditors? } \\
\text { What impact does the rise of BDA have on } \\
\text { auditors' actual and perceived ability to achieve } \\
\text { audit quality? Ia BDA producing better audits? } \\
\text { What should be the appropriate way for the audit } \\
\text { regulators and standard setters to accommodate the } \\
\text { current developments with BDA and auditing into } \\
\text { auditing standards and regulations? }\end{array}$ \\
\hline $\begin{array}{l}\text { Economic } \\
\text { Impact of BDA on the economics of } \\
\text { auditing and the position of audit } \\
\text { within multi-disciplinary audit firm } \\
\text { contexts. }\end{array}$ & $\begin{array}{l}\text { What role do the audit firms' strategies for } \\
\text { business expansion and commercialistic } \\
\text { motivations play in the promotion of BDA? } \\
\text { What is the relationship between BDA and the cost } \\
\text { of auditing? } \\
\text { What is the actual impact of BDA on the shifting } \\
\text { boundaries between audit and non-audit services? } \\
\text { Is audit function alone capable of generating } \\
\text { resources sufficient for the development and } \\
\text { management of BDA tools? Consequently, does } \\
\text { BDA reflect purely an audit mindset? } \\
\text { What are the consequences of BDA for potential } \\
\text { marginalization of auditing within audit firms' } \\
\text { service portfolios? } \\
\text { To what extent is the rise of BDA potentially } \\
\text { contributing to a perception of audit as a supplier } \\
\text { of knowledge spillovers for the audit firms; other } \\
\text { service lines? } \\
\text { What is the effects of the claimed benefits of BDA } \\
\text { (such as with regards to full population testing) on } \\
\text { the scope of litigation against auditors? }\end{array}$ \\
\hline $\begin{array}{l}\text { Professional } \\
\text { Impact of BDA on the notions of } \\
\text { accounting professionalism. }\end{array}$ & $\begin{array}{l}\text { Do auditors possess the expertise and knowledge } \\
\text { required for BDA environments? } \\
\text { Is the rise of BDA in auditing potentially altering } \\
\text { the nature of skillsets required of a modern auditor } \\
\text { (towards more technical competencies)? }\end{array}$ \\
\hline
\end{tabular}




\begin{tabular}{|l|l|}
\hline $\begin{array}{l}\text { Does audit practice in the era of BDA provide a } \\
\text { suitable environment for the development of } \\
\text { auditors as professionals? }\end{array}$ \\
$\begin{array}{l}\text { What are the consequences of BDA for the image } \\
\text { of audit work as intellectual inference-based } \\
\text { practice? }\end{array}$ \\
$\begin{array}{l}\text { Can the rise of BDA potentially generate } \\
\text { significant deskilling and de-professionalizing } \\
\text { effects? }\end{array}$ \\
$\begin{array}{l}\text { Can BDA ultimately be judged as a destructive } \\
\text { innovation (the prospect of an "auditorless audit)"'? }\end{array}$
\end{tabular}

